The Basement of the Deccan Traps and Its Madagascar Connection: Constraints from Xenoliths Author(s): Dewashish Upadhyay, Ellen Kooijman, Ajay K. Singh, Klaus Mezger, and Jasper Berndt

Source: The Journal of Geology, Vol. 123, No. 3 (May 2015), pp. 295-307

Published by: The University of Chicago Press

Stable URL: http://www.jstor.org/stable/10.1086/682009

Accessed: 30/07/2015 06:58

Your use of the JSTOR archive indicates your acceptance of the Terms \& Conditions of Use, available at http://www.jstor.org/page/info/about/policies/terms.jsp

JSTOR is a not-for-profit service that helps scholars, researchers, and students discover, use, and build upon a wide range of content in a trusted digital archive. We use information technology and tools to increase productivity and facilitate new forms of scholarship. For more information about JSTOR, please contact support@jstor.org. 


\title{
The Basement of the Deccan Traps and Its Madagascar Connection: Constraints from Xenoliths
}

\author{
Dewashish Upadhyay, ${ }^{1, \star}$ Ellen Kooijman, ${ }^{2}$ Ajay K. Singh, ${ }^{1}$ \\ Klaus Mezger, ${ }^{3}$ and Jasper Berndt ${ }^{4}$
}

1. Department of Geology and Geophysics, Indian Institute of Technology, Kharagpur, India; 2. Department of Geosciences, Swedish Museum of Natural History, Frescativägen 40, SE-11418 Stockholm, Sweden; 3. Institute for Geology and Center for Space and Habitability, University of Bern, Baltzerstrasse 1+3 CH-3012 Bern, Switzerland;

4. Institute for Mineralogy, Westfälische Wilhelms-University, Corrensstrasse 24, 48149 Münster, Germany

\begin{abstract}
A B S T R A C T
Paleogeographic reconstructions of India and Madagascar before their late Cretaceous rifting juxtapose the Antongil Block of Madagascar against the Deccan Traps of India, indicating that the Western Dharwar Craton extends below the Deccan lavas. Some recent studies have suggested that the South Maharashtra Shear Zone along the northern Konkan coast of India limits the northern extent of the Western Dharwar Craton, implying that the craton does not extend below the Deccan Traps, raising a question mark on paleogeographic reconstructions of India and Madagascar. The continuity of the Western Dharwar Craton north of the South Maharashtra Shear Zone below the Deccan Traps-or its lack thereof-is critical for validating tectonic models correlating Madagascar with India. In this study, zircons in tonalitic basement xenoliths hosted in Deccan Trap dykes were dated in situ, using the U-Pb isotope system. The data furnish U-Pb ages that define three populations at $2527 \pm 6,2456 \pm 6$, and $2379 \pm 9 \mathrm{Ma}$. The $2527 \pm 6 \mathrm{Ma}$ ages correspond to the igneous crystallization of the tonalites, whereas the $2456 \pm 6$ and $2379 \pm 9$ Ma ages date metamorphic overprints. The results help to establish for the first time that the basement is a part of the Neoarchean granitoid suite of the Western Dharwar Craton, which extends northward up to at least Talvade in central and Kihim beach in the western Deccan. By implication, the South Maharashtra Shear Zone cannot be the northern limit of the Western Dharwar Craton. The granitoids are correlated with the Neoarchean felsic intrusions (2.57-2.49) of the Masaola suite in the Antongil Block of Madagascar, supporting the existence of a Neoarchean Greater Dharwar Craton comprising the Western Dharwar Craton and the Antongil-Masora Block.
\end{abstract}

Online enhancements: supplementary table.

\section{Introduction}

Paleogeographic reconstructions suggest a close link between India and Madagascar from the late Neoproterozoic/early Paleozoic (McWilliams 1981; Stern 1994; Meert et al. 1995; Blasband et al. 2000; De Wit 2003; Sommer et al. 2003; Veevers 2004 ; Collins and Pisarevsky 2005; Ratheesh Kumar et al. 2014) until their separation in the late Cretaceous (Storey et al. 1995; Torsvik et al. 1998, 2000; fig. 1). The present-day crystalline basement of Madagascar is made up of Archean to Neo-

Manuscript received August 19, 2014; accepted April 10, 2015; electronically published May 27, 2015.

* Author for correspondence; e-mail: dewashish@gg.iitkgp .ernet.in. proterozoic crustal units with equivalents in India and East Africa (Stern 1994; Unrug 1996; Blasband et al. 2000; Kröner et al. 2000; Veevers 2004; Collins and Pisarevsky 2005). The Antongil-Masora Block of Madagascar can be correlated with the Western Dharwar Craton (WDC) of India on the basis of the coherent Paleo/Mesoarchean and Neoarchean evolutionary histories of the two crustal units (e.g., Tucker et al. 1999b, 2011a, 2011b, 2014; Schofield et al. 2010; Rekha et al. 2013; 2014). Together, the two terranes constituted the Greater Dharwar Craton (GDC). According to Collins et al. (2003) and others (Collins and Windley 2002; Cox et al. 2004; Fitzsimons and Hulscher 2005; Collins 2006), the Neoarchean Antananarivo Block of present-day

[The Journal of Geology, 2015, volume 123, p. 295-310] (C) 2015 by The University of Chicago. All rights reserved. 0022-1376/2015/12303-0005\$15.00. DOI:10.1086/682009 


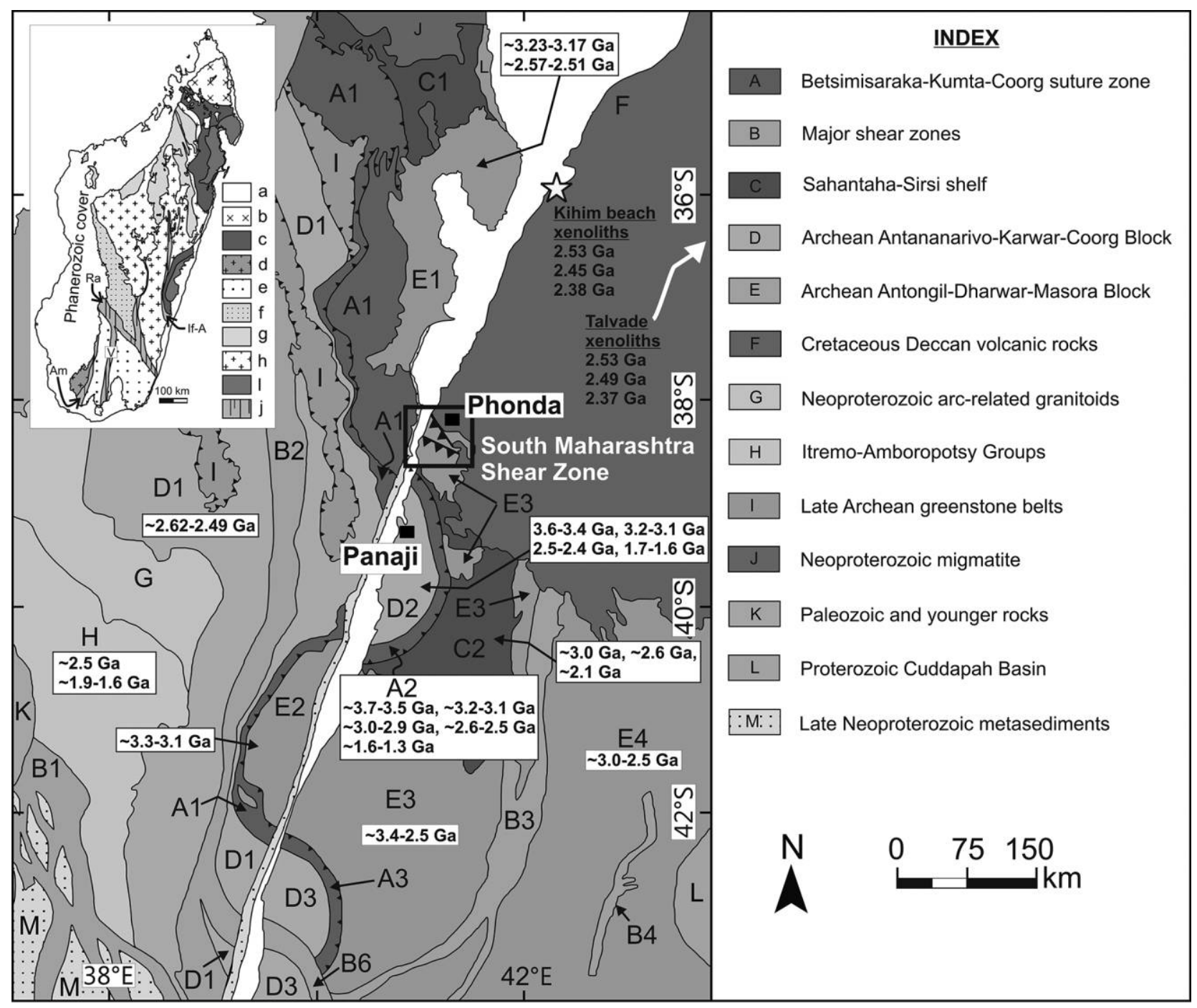

Figure 1. Juxtaposition of India and Madagascar at $120 \mathrm{Ma}$ and suggested correlation of shear zones and tectonic units, as proposed by Ishwar Kumar et al. (2013). The published ages of the crustal units in western India and northcentral Madagascar are shown (age data compiled from Balasubramanian et al. 1978; Swami Nath and Ramakrishnan 1981; Naqvi and Rogers 1987; Gupta et al. 1988; Agarwal et al. 1992; Jayananda et al. 1995, 2000; Peaucat et al. 1995; Russel et al. 1996; Tucker et al. 1999b, 2011b, 2014; Chawwick et al. 2000; Paquette et al. 2003; Ghosh et al. 2004; French and Heaman 2010; Schofield et al. 2010; Ishwar Kumar et al. 2013; Rekha et al. 2013). A major part of the Peninsular Indian basement along the Konkan coast is covered and hidden by volcanic rocks of the Deccan Traps, making reliable correlations with Madagascar difficult. The South Maharashtra Shear Zone-which Rekha et al. $(2013,2014)$ and Rekha and Bhattacharya (2014) claim to represent the northern boundary of the WDC-is marked. The new U-Pb zircon ages from basement xenoliths in Deccan Traps dykes help to establish the northern continuity of the Western Dharwar Craton and its correlation with crustal units in northern Madagascar. Abbreviations: A1, Betsimisaraka suture zone; A2, Kumta suture zone; A3, Coorg suture zone; B1, Ranotsara shear zone; B2, Angavo shear zone; B3, Chitradurga shear zone; B4, Kolar shear zone; B6, Moyar shear zone; C1, Sahantaha shelf; C2, Sirsi shelf; D1, Antananarivo block; D2, Karwar block; D3, Coorg block; E1, Antongil block; E2, Masora block; E3, Western Dharwar Craton; E4, Eastern Dharwar Craton. Inset is an overview geological map of Madagascar showing the major tectonic units. Abbreviations: a, Phanerozoic cover; b, Bemarivo Belt; c, Betsimisaraka Unit; d, Vohibory Unit; e, Androyen Unit; f, Molo Unit; g, Tsaratanana Sheet; h, Antananarivo Block; i, Antongil-Masora Block; j, shear zone systems (Am, Ampanihy; Be, Betsileo; If-A, Ifanadiana-Angavo; Ra, Ranotsara; V, Vorokafotra). A color version of this figure is available online. 
Madagascar having East African affinity was amalgamated with India during the early Cambrian collision of the GDC with the Antananarivo Block along the Betsimisaraka Suture. This view is strongly contested by Tucker and coworkers (e.g., Tucker et al. 2011a, 2014), who have questioned the existence of such a suture. These authors propose that the Archean rocks of present-day Madagascar-represented by the Antongil-Masora and Antananarivo domains-were part of the GDC since ca. 3.0 Ga until its fragmentation in the Cretaceous. They also suggest that the Antananarivo Block was amalgamated within the GDC during a Neoarchean (2.55$2.48 \mathrm{Ga}$ ) accretion event. The Paleoproterozoic Anosyen-Androyen unit in southern Madagascar was sutured with the GDC-which comprised the WDC, the Antongil-Masora Block, and the Antananarivo Block-during Ediacaran-early Cambrian time along the Ranotsara-Bongolava shear zone (fig. 1).

A reconstruction of India and Madagascar at ca. $120 \mathrm{Ma}$ (e.g., Katz and Premoli 1979; Collins and Windley 2002; Meert 2003; O'Neill et al. 2003; Ishwar Kumar et al. 2013) just before their rifting juxtaposes the Antongil Block of Madagascar against the late Cretaceous to Paleocene (Lightfoot et al. 1987; Vandamme et al. 1991; Sheth et al. 2001; Mahoney et al. 2002; Pande 2002) Deccan Traps of India (fig. 1). If the Antongil Block and the WDC constituted an expansive GDC until the late Cretaceous, the WDC should extend below the Deccan Trap lavas. Recently, Rekha et al. $(2013,2014)$ and Rekha and Bhattacharya (2014) have identified a new Paleoproterozoic/Mesoproterozoic shear zone system called the Pernem-Phonda tectonic zone/South Maharashtra Shear Zone between Pernem and Phonda along the northern Konkan coast of western India (fig. 1). These authors claim that the shear zone system is a terrane boundary that limits the northern extent of the WDC. By implication, the WDC does not extend below the Deccan Traps. If true, the Antongil Block would have no counterpart in peninsular India, requiring a relook at the paleogeographic reconstructions of India and Madagascar.

Thus, the continuity of the WDC north of the South Maharashtra Shear Zone-or its lack thereof-is critical for the validation of tectonic models correlating India and Madagascar. Unfortunately, a major part of the Peninsular Indian basement (>500,000 $\mathrm{km}^{2}$; Ray et al. 2008) along the Konkan coast north of the South Maharashtra Shear Zone is covered and hidden by volcanic rocks of the Deccan Traps (figs. 1, 2). As a result, the nature and the geological-geochronological evolution of the basement rocks underlying the Deccan lavas are unconstrained.
In this contribution, we report, for the first time, laser ablation-sector field-inductively coupled plasma mass spectrometer (LA-SF-ICP-MS) $\mathrm{U}-\mathrm{Pb}$ zircon isotope ages from the rocks derived from the basement below the Deccan Traps. These rocks are exposed as crustal xenoliths in basaltic dykes in the central and western Deccan Traps (fig. 2). The new data help to establish the northern continuity of the WDC and its correlation with crustal units in northern Madagascar.

\section{Regional Geology and Field Setting}

The Western Dharwar Craton. The WDC comprises Paleo- to Mesoarchean (3.4-3.0 Ga) tonalitetrondhjemite-granodiorite basement referred to as the Peninsular gneisses (Beckinsale et al. 1980; Taylor et al. 1984; Dhoundial et al. 1987; Meen et al. 1992; Peucat et al. 1993; Ishwar Kumar et al. 2013; fig. 2). The basement is overlain by two greenstonetype supracrustal sequences that have been subdivided into the amphibolite to granulite facies Sargur Group of Paleo- to Mesoarchean (3.3-3.1 Ga) age and the greenschist facies Dharwar Supergroup of Neoarchean (3.0-2.6 Ga) age (Swami Nath et al. 1976; Janardhan et al. 1979; Nutman et al. 1992; Bouhallier et al. 1993, 1995; Peucat et al. 1995; Ramakrishnan and Vaidyanadhan 2008). The Dharwar Supergroup has been subdivided into two volcano-sedimentary successions, an older Bababudan Group overlain by the younger Chitradurga Group, separated by a disconformity (Swami Nath and Ramakrishnan 1981). The Bababudan Group comprises metamorphosed basalts, layered mafic complexes, mafic/ultramafic schists, and felsic volcanic units together with metasedimentary rocks, such as quartzite, phyllite, and banded iron formations. The Chitradurga Group is made up of metasedimentary rocks, such as orthoquartzite, graywacke, conglomerate, banded iron formation, phyllite, and carbonate interlayered with metavolcanic units. The two volcano-sedimentary successions form the Shimoga and Chitradurga greenstone belts (Swami Nath et al. 1976). The craton underwent a major phase of felsic magmatism accompanied by deformation and metamorphism during the late Neoarchean $(2.6-2.4 \mathrm{Ga})$ related to the amalgamation of the Western and Eastern Dharwar Cratons (Friend and Nutman 1991; Chadwick et al. 2000; Moyen et al. 2003; Peucat et al. 2007; Chardon and Jayananda 2008) and the closure of the Goa basin (Rekha et al. 2013). The final phase of igneous activity is represented by the emplacement of mafic dyke swarms at 2.4, 2.0-2.2, and 1.6 Ga (French and Heaman 2010 and references therein). 
Recently, Ishwar Kumar et al. (2013) have identified a new arcuate paleo-suture called the Kumta suture zone along the western coast of India. This belt is purported to be the extension of the Betsimisaraka Suture of Madagascar into western India (fig. 1). The suture separates the Sirsi shelf (Dharwar supracrustals) of the Dharwar cratonic block from the Karwar block (Ishwar Kumar et al. 2013), which comprises tonalite-trondhjemite-granodiorite and amphibolites equivalent to the Peninsular gneisses.

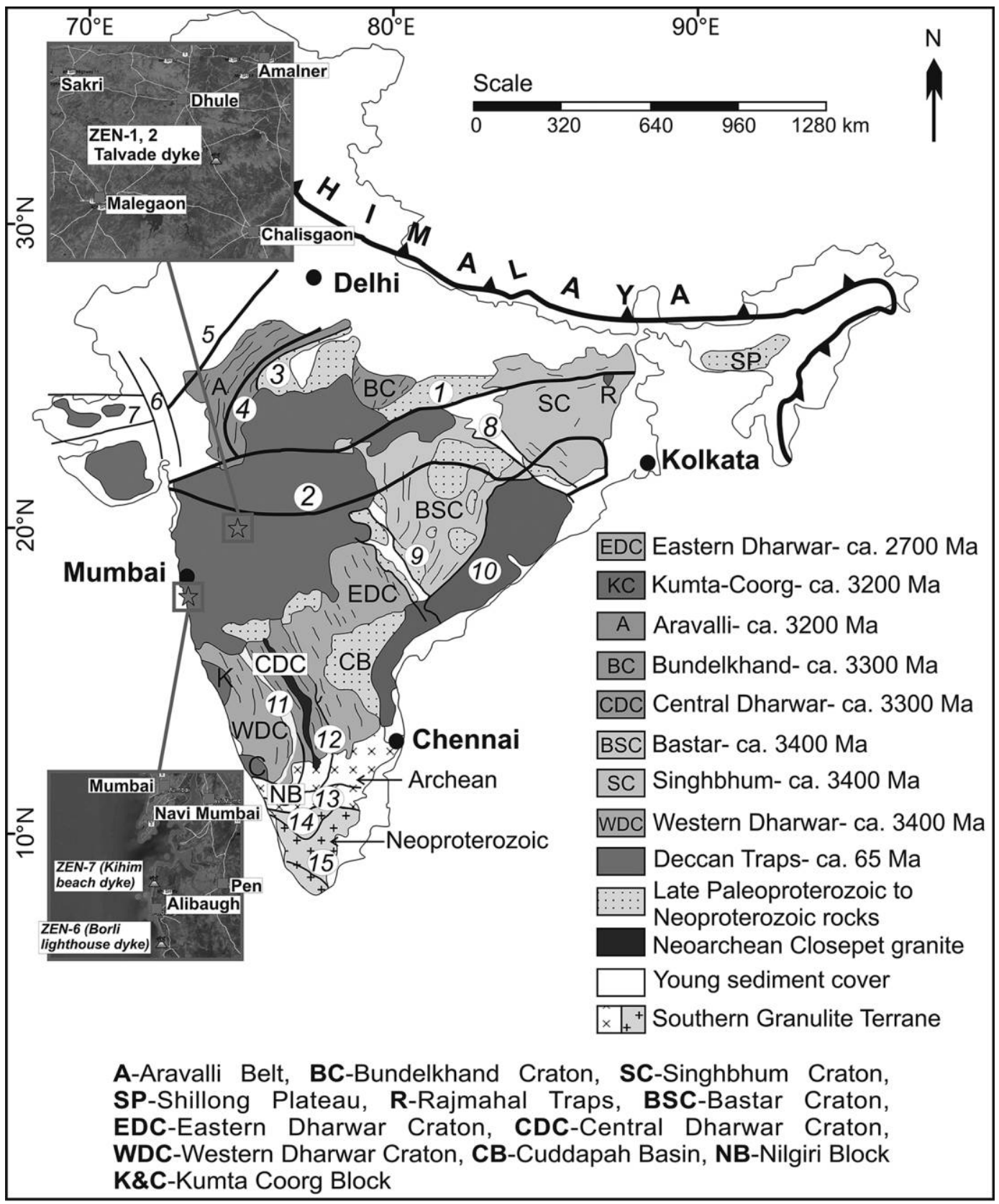

Figure 2. Generalized geological map of peninsular India showing the broad lithotectonic units (modified from Ratheesh Kumar et al. 2014). The Deccan Trap volcanic rocks and the location of Talvade (GPS coordinates: lat $20^{\circ}$ $40.24^{\prime} \mathrm{N}$, long $74^{\circ} 52.37^{\prime} \mathrm{E}$ ) and Kihim beach (GPS coordinates: lat $18^{\circ} 43.85^{\prime} \mathrm{N}$, long $72^{\circ} 51.88^{\prime} \mathrm{E}$ ) xenolith-bearing basaltic dykes are marked with stars. Insets are Google Earth images showing the exact locations of the two dykes. Rifts, shear/suture zones, and mobile belts: 1, Narmada-Son; 2, Satpura Mobile Belt; 3, Great Boundary Fault; 4, Aravalli Fold Belt; 5, Delhi Fold Belt; 6, Cambay Rift; 7, Kutch Rift; 8, Mahanadi Rift; 9, Godavari Rift; 10, Eastern Ghats Mobile Belt; 11, Chitradurga shear zone; 12, Mettur-Kolar shear zone; 13, Palghat-Cauvery shear system; 14, KarurKamban-Painavu-Trichur shear zone; 15, Achankovil shear zone. A color version of this figure is available online. 
On the basis of the correlation of various shear zones in a reconstruction of India and Madagascar at $120 \mathrm{Ma}$, Ishwar Kumar et al. (2013) suggested that the Antananarivo-Karwar-Coorg block (2500$3200 \mathrm{Ma})$ in the west and the GDC ( 2571 Ma) in the east were amalgamated along the BetsimisarakaKumta-Coorg suture (fig. 1) diachronously from north to south in the period 1380-750 Ma.

The Deccan Traps and Related Dyke Swarms. The Deccan Traps represent an expansive continental flood basalt province with a composite thickness of ca. $3000 \mathrm{~m}$ and covering an area of more than $500,000 \mathrm{~km}^{2}$ of the Indian Peninsula (fig. 2). The volcanic rocks are dominated by subaerial flows of tholeiitic basalts with minor occurrences of picrites and alkali basalts (e.g., Beane et al. 1986). The flood basalts were erupted close to the CretaceousTertiary boundary (61-72 Ma; Lightfoot et al. 1987; Vandamme et al. 1991; Sheth et al. 2001; Mahoney et al. 2002; Pande 2002).

The xenolith samples were collected from two E-W-trending dykes at Talvade near Dhule in the central and at Kihim beach near Alibaugh in the western part of the Deccan Traps (fig. 2). The Talvade dyke forms a part of the large Narmada-Satpura-Tapi giant dyke swarm of tholeiitic basalts outcropping in the Nandurbar-Dhule region of the central Dec- can Traps (Sant and Karanth 1990; Ray et al. 2007). The swarm covers an area of $\sim 14,500 \mathrm{~km}^{2}$ and contains about 210 dykes of dolerite and basalt intrusive into compound pahoehoe flows of basaltic composition (Ray et al. 2007, 2008). All dykes strike $\mathrm{E}-\mathrm{W}$ and have been interpreted to be related to the $\sim$ N-S regional minimum horizontal compressive stress $\left(\sigma_{3}\right)$ direction.

The Talvade dyke is $18 \mathrm{~km}$ long, ca. $3 \mathrm{~m}$ wide, and of basaltic composition (Ray et al. 2008). The dyke contains an assorted variety of xenoliths that are concentrated in the upper part of the dyke along the ridge crest (fig. 3; cf. Ray et al. 2008). The xenoliths are usually angular to tabular and span a wide range of sizes, from millimeter-sized fragments to rafts tens of centimeters across (fig. 3). The rock types include granite gneiss, tonalite gneiss, granite, quartzite, vein quartz, feldspathic granulite, calcareous rock, and fine-grained tuff (this study; Ray et al. 2008). Some of the quartzite and gneissic xenoliths preserve megascopic folds and mylonitic bands (cf. Ray et al. 2008).

The Kihim beach dyke forms a part of the NNWSSE-trending Konkan dyke swarm outcropping along the Konkan plain (Dessai and Viegas 1995; Ray et al. 2007). The dykes of the Konkan swarm display a large compositional variation from tho-
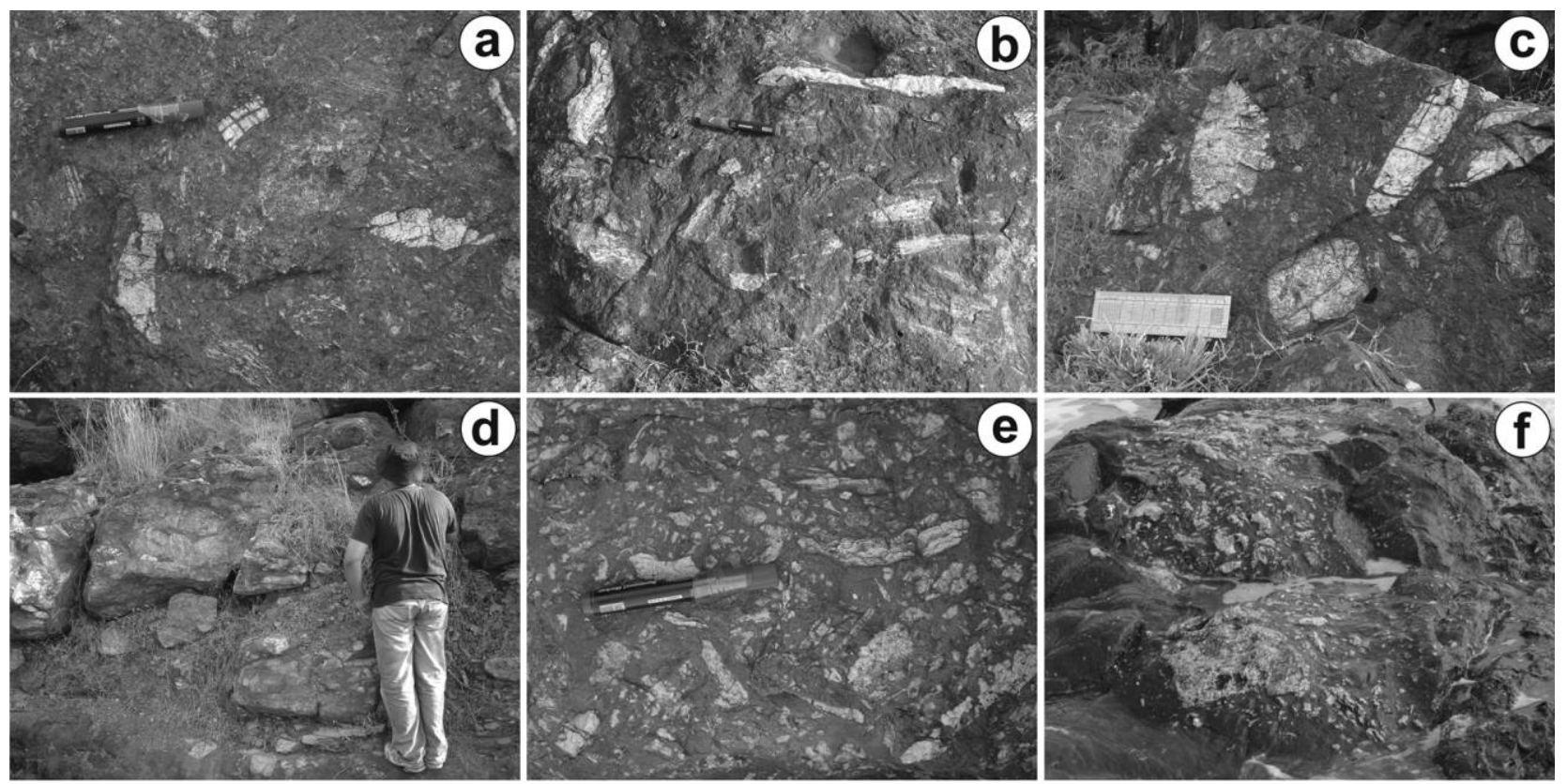

Figure 3. Field photographs documenting the occurrence of an assorted variety of basement xenoliths in basaltic dykes at Talvade $(a-e)$ and Kihim beach $(f)$. The xenoliths are concentrated in the upper central part of the dyke along the ridge crest. They span a wide range of sizes, from millimeter-sized fragments to rafts tens of centimeters across, and include rock types such as granite gneiss, tonalite gneiss, granite, quartzite, vein quartz. Many of the xenoliths are fragmented and heavily altered. A color version of this figure is available online. 
leiitic to alkalic, ultramafic to silicic and carbonatitic. The Kihim beach dyke is of basaltic composition and contains numerous granitic and tonalitic xenoliths concentrated along the upper central part of the dyke (fig. 3). The size of the xenoliths is variable, from a few millimeters to several centimeters across. In both the Talvade and Kihim beach dykes, basaltic lava has been injected along the foliation/layering of the xenoliths and grain boundaries of the minerals. As a result, many of the xenoliths are fragmented and heavily altered.

North-Central Madagascar. North-Central Madagascar has been divided into five tectonic units (Collins et al. 2000; Kröner et al. 2000; Collins and Windley 2002; Tucker et al. 2011b, 2014; fig. 1): (1) the Antongil-Masora Block, comprising Paleoto Mesoarchean $(\sim 3.2 \mathrm{Ga})$ gneisses intruded by Neoarchean $(\sim 2.5 \mathrm{Ga})$ granites metamorphosed under greenschist facies conditions (Tucker et al. 1999b; Collins et al. 2001; Schofield et al. 2010); (2) the Antananarivo Block, consisting of $\sim 2.5$-Ga gneisses interlayered with 820-740-Ma granitoids and gabbros, deformed and metamorphosed at high-grade conditions between 700 and $550 \mathrm{Ma}$ (Tucker et al. 1999b; Kröner et al. 2000; Collins et al. 2003); (3) the Itrimo sheet, comprising Paleo- to early Neoproterozoic deformed metasedimentary rocks (Cox et al. 1998; Collins et al. 2003) that have been thrust over the Antananarivo block; and (4) the Tsaratanana sheet, consisting of mafic gneisses having an age of 2.8-2.5 Ga (U-Pb zircon) and yielded Meso- to Neoarchean xenocrystic zircon and Sm-Nd ages (Tucker et al. 1999b; Collins et al. 2001). The Tsaratanana sheet rocks have been multiply deformed/metamorphosed at $\sim 2.5 \mathrm{Ga}$ and $\sim 0.5 \mathrm{Ga}$ and cut by 800 $760 \mathrm{Ma}$ gabbro intrusions (Goncalves et al. 2000); (5) the Bemarivo belt made up of metasediments, granites, and gneisses overlain by deformed metavolcanic rocks metamorphosed under granulite facies conditions at 510-520 Ma (Tucker et al. 1999a). The crustal blocks of central and northern Madagascar are separated from southern Madagascar by the Ranotsara shear zone (Windley et al. 1994).

\section{Analytical Techniques}

Zircon grains from granitic/tonalitic xenoliths in the Talvade and Kihim beach dykes were dated in situ in thin sections using a LA-SF-ICP-MS at the Institut für Mineralogie, Westfälische WilhelmsUniversität, Münster. The internal structures of the grains were imaged by cathodoluminescence (CL) and back-scattered electron (BSE) techniques, using a JEOL JSA 6490 secondary electron microscope at the Department of Geology and Geo- physics, Indian Institute of Technology, Kharagpur. The U-Pb isotope measurements were done on a Thermo-Fisher Scientific Element 2 SF-ICP-MS coupled to a New Wave UP193HE ArF Excimer laser system. The laser was operated at a $10-\mathrm{Hz}$ repetition rate, $5-\mathrm{J} / \mathrm{cm}^{2}$ beam energy density, and 12$35-\mu \mathrm{m}$ spot size. External standardization was done by bracketing groups of 10 unknowns with three measurements of the GJ-1 reference zircon (Jackson et al. 2004). Further details of the analytical and data reduction protocols can be found in Kooijman et al. (2012). Selection of laser ablation spots was based on the internal structure of grain interiors as seen in CL and BSE images. To monitor precision and accuracy, the 91500 reference zircon (Wiedenbeck et al. 1995) was measured $(n=62)$ as unknowns over the course of the analyses and yielded ${ }^{206} \mathrm{~Pb} /{ }^{238} \mathrm{U}=0.179( \pm 1.5 \%, 2 \sigma)$ and ${ }^{207} \mathrm{~Pb} /{ }^{206} \mathrm{~Pb}=$ $0.0749( \pm 0.99 \%, 2 \sigma)$, which match published values within analytical errors. All uncertainties are reported at the $2 \sigma$ level. The $\mathrm{U}$ contents were estimated relative to the GJ-1 reference zircon. Concordia diagrams were constructed using Isoplot 4.15 (Ludwig 2003). The U-Pb isotope ratios and ages are listed in table S1, available online.

\section{Results}

Petrographic Description. Four granitoid xenolith samples were selected for the study. Three of them (ZEN-1C, ZEN-2a, ZEN-2c) are from the Talvade dyke, whereas the fourth (ZEN-7a) is from the Kihim beach dyke.

ZEN-1C. This is a quartzofeldspathic rock having two distinct textural domains. One of the domains is strongly foliated, with the foliation plane defined by stretched quartz lenticels showing dynamic recrystallization (fig. 4a). Basaltic melt is seen to have intruded between the foliation planes (fig. 4a) as well as along grain boundaries of minerals (fig. 4d). Evidence of residual strain is seen in the form of undulose extinction in quartz. The dynamically recrystallized quartz grains are overprinted by partial static annealing producing $120^{\circ}$ triple junctions. This annealing is possibly related to the heating of the xenolith within the basaltic host magma. The other domain is relatively coarse grained, with coarse-scale layering comprising alternate quartz-rich and plagioclase-rich layers (fig. $4 b$ ). The plagioclase is extensively altered and appears cloudy (fig. $4 b-4 d$ ). Inclusion of iron oxide within grains and along fractures/cracks imparts a dark color to the grains (fig. 4b). The quartz is coarse grained, weakly strained, and equigranular. Euhedral zircons occur within quartz and plagioclase as 


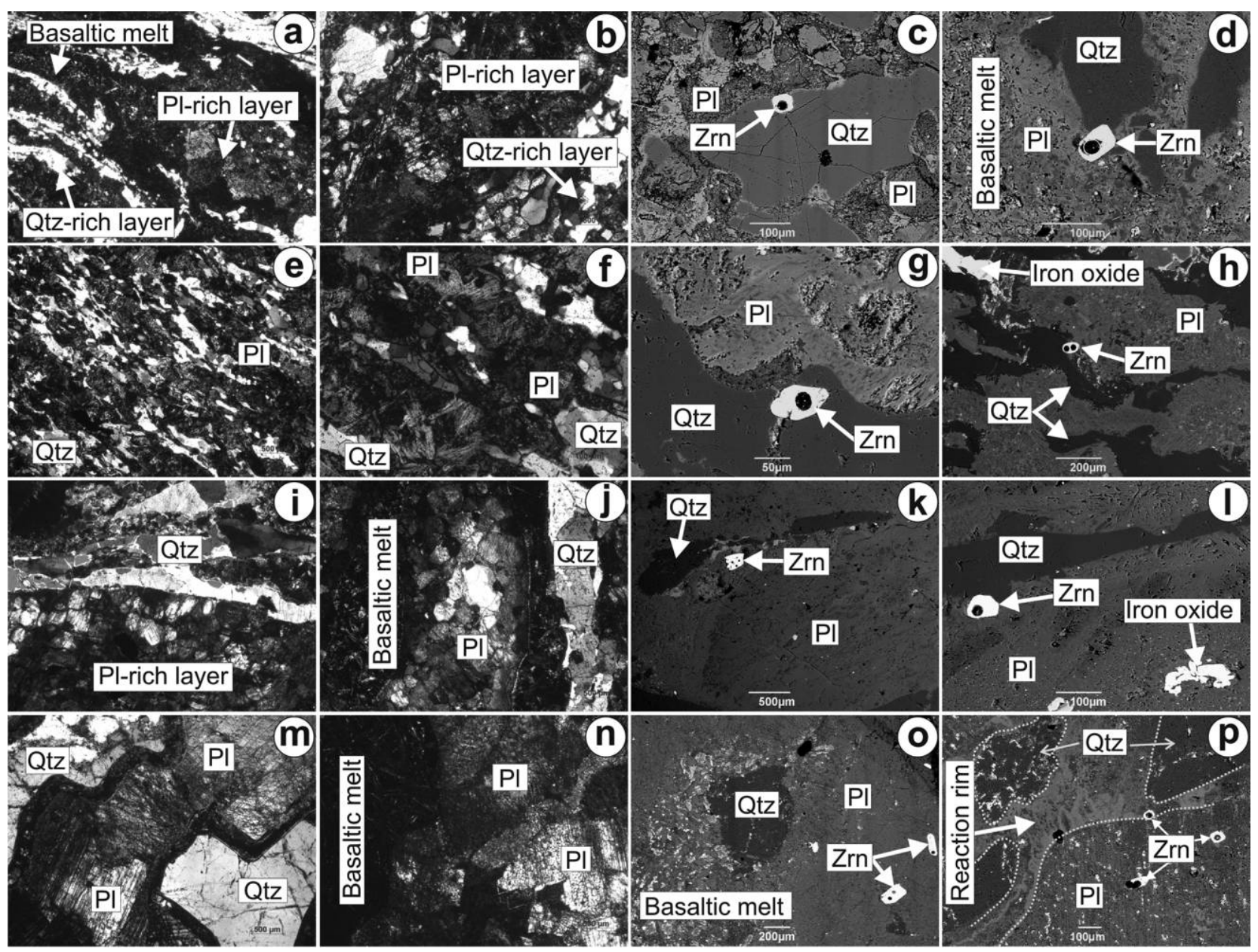

Figure 4. Plane-polarized light photomicrographs (left columns) and BSE images (right columns) illustrating microtextural relationships in the tonalite/tonalite gneiss basement xenoliths: ZEN-1C $(a-d)$, ZEN-2A $(e-h), Z$ EN-2C $(i-1)$, ZEN-7A $(m-p)$. Extensive alteration of feldspars is observed especially in domains where basaltic melt has intruded the xenoliths. A color version of this figure is available online.

well as along the contact between the two minerals (fig. 4c, 4d). Quartz crystals show evidence for resorption (fig. 4d).

$Z E N-2 A$. The rock is tonalite gneiss with a strong tectonic foliation defined by alternate quartzrich and feldspar-rich layers (fig. 4e). Quartz grains are stretched to lenticels and show undulose extinction and subgrain formation (fig. 4f). The feldspars are mostly plagioclase and show extensive alteration. They appear clouded and contain opaque (iron oxide) inclusions (fig. 4e-4h). There is extensive iron oxide staining/impregnation along cleavages and grain boundaries (fig. $4 f-4 h$ ). The quartz has recrystallized to a very fine aggregate and is full of mineral and fluid inclusions. Zircons are euhedral to subhedral and occur largely in quartz or at the quartz-plagioclase grain boundaries (fig. $4 g, 4 h$ ).

$Z E N-2 C$. This is relatively coarse-grained tonalite gneiss. The foliation is defined by coarse grains of elongated quartz alternating with plagioclaserich layers (fig. 4e). The plagioclase grains show extensive alteration manifested by porosity formation, clouding of the grains, patches of iron oxide inclusions, fluid inclusions, as well as sericite and zoisite inclusions (fig. 4i-41). The coarse elongated plagioclase laths are recrystallized to a granoblastic mosaic with $120^{\circ}$ triple junctions (fig. 4i, 4j). Veins and pockets of basaltic melt intrude the xenolith along foliation. These interfaces are characterized by extensive plagioclase alteration (fig. 4j-41). Zircon occurs both in quartz as well as within altered plagioclase.

$Z E N-7 A$. This is a very coarse-grained rock comprising mostly plagioclase, with some interstitial quartz. The rock can be classified as a tonalite (fig. $4 \mathrm{~m}$ ). It contains veins and pockets of the host basaltic melt, along which there is extensive alteration of the plagioclase, as in the other samples 
(fig. $4 n-4 p$ ). The altered plagioclase is porous and full of iron oxide inclusions (fig. 4o, $4 p$ ). Quartz grains show evidence of resorption (fig. 4o, $4 p$ ). A thick reaction rim has developed at the mineralmelt and mineral-mineral interface (fig. $4 m, 4 p$ ).

Zircon Internal Structure and U-Pb Ages. Tonalite (ZEN-1C). Laser ablation analyses of core and rim regions in 16 grains furnish concordant as well as discordant spot ages. The data points define a discordia with an upper intercept age of $2521 \pm 10 \mathrm{Ma}$ and a lower intercept age of $90 \pm 15 \mathrm{Ma}$ (MSWD = 2; fig. 5). The young lower intercept age indicates alteration/ $\mathrm{Pb}$ loss of the zircons during the eruption and entrainment of the xenoliths within the Deccan Trap lavas. Therefore, the ${ }^{207} \mathrm{~Pb} /{ }^{206} \mathrm{~Pb}$ ages from even the discordant data points may represent the real formation ages, especially since most of them cluster within a relatively narrow range. The ${ }^{207} \mathrm{~Pb} /$ ${ }^{206} \mathrm{~Pb}$ ages define three age populations at $2527 \pm 8$, $2487 \pm 13$, and $2373 \pm 28 \mathrm{Ma}$. The $2527 \pm 8 \mathrm{Ma}$ cluster is identical to the discordia upper intercept age and was measured from domains displaying prominent to relict oscillatory growth zoning (fig. $5 b$, grains $10,18,19$, and 20 ). The $2527 \pm 8 \mathrm{Ma}$ age is therefore interpreted as the emplacement age of the tonalite. Many of the zircons show evidence of fluid/melt-assisted alteration. In BSE images, such grains appear pitted with the development of macroporosity (e.g., grain 3, fig. $5 b$ ). In CL images, these zircons show CL-weak alteration patches/ layers along cracks/fractures (e.g., grains 3 and 7, fig. $5 b$ ). The discordant data points were measured from grains showing these alteration features. Their ${ }^{207} \mathrm{~Pb} /{ }^{206} \mathrm{~Pb}$ ages define a major age cluster at $2487 \pm$ $13 \mathrm{Ma}$ and a minor one at $2373 \pm 28 \mathrm{Ma}$, both of which are attributed to late Neoarchean to early Paleoproterozoic metamorphism of the tonalite.

Tonalite gneiss (ZEN-2A). Most zircon spot analyses give discordant ages that define a discordia indicating near-recent alteration and $\mathrm{Pb}$ loss (fig. 6). Thus, the ${ }^{207} \mathrm{~Pb} /{ }^{206} \mathrm{~Pb}$ ages from even the discordant data points are likely to date real geological events. At the least, they are minimum ages and likely to be geologically significant, since most of them cluster closely together. The ${ }^{207} \mathrm{~Pb} /{ }^{206} \mathrm{~Pb}$ ages define two populations: one at $2521 \pm 21 \mathrm{Ma}$, measured from U-poor CL-bright domains that preserve prominent-to-faint oscillatory growth zo-

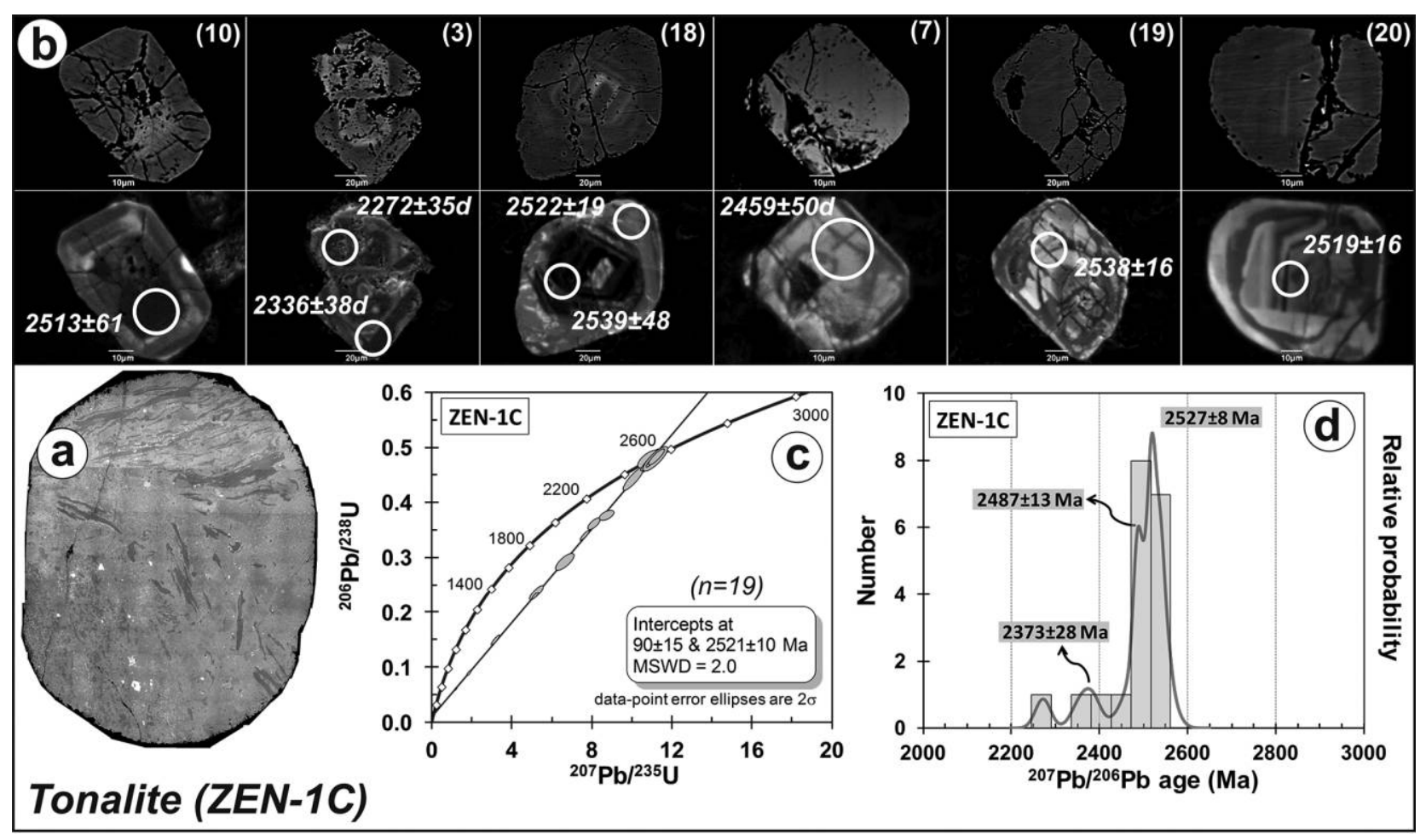

Figure 5. Collage of BSE images showing the overall texture of the tonalite xenolith ZEN-1C $(a)$, BSE and CL images of zircons from the sample with the spot ages marked ( $d$ indicates discordant analysis; $b$ ), concordia $(c)$, and ${ }^{207} \mathrm{~Pb} /{ }^{206} \mathrm{~Pb}$ age relative probability density plots $(d)$, respectively, of $\mathrm{U}-\mathrm{Pb}$ isotope data from zircons. Age populations were computed using the unmix ages option in Isoplot, which uses the unmixing algorithm of Sambridge and Compston (1994). A color version of this figure is available online. 


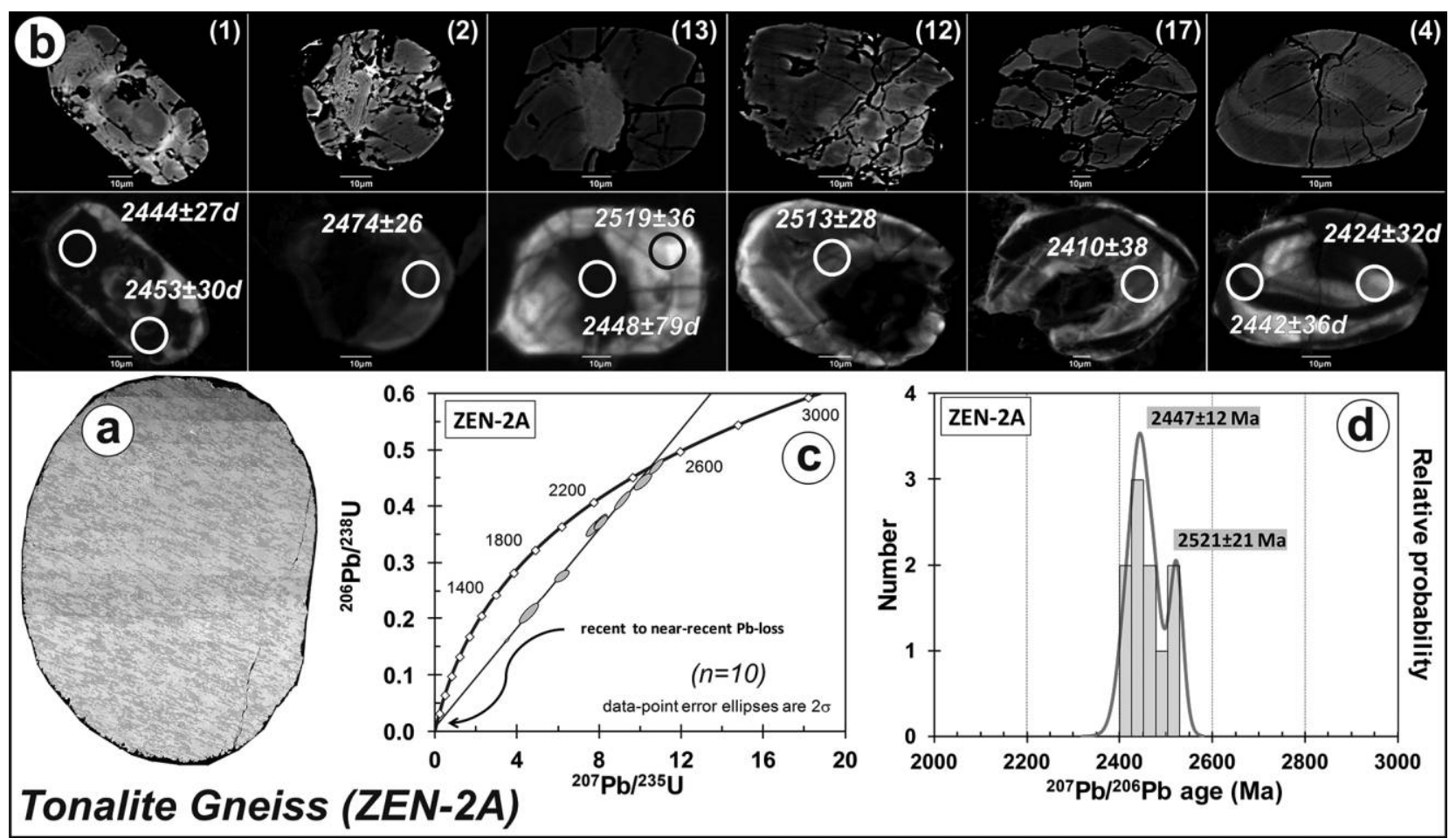

Figure 6. Collage of BSE images showing the overall texture of the tonalite xenolith ZEN-2A $(a)$, BSE and CL images of zircons from the sample with the spot ages marked $(d$ indicates discordant analysis; $b)$, concordia $(c)$, and ${ }^{207} \mathrm{~Pb} /{ }^{206} \mathrm{~Pb}$ age relative probability density plots $(d)$, respectively, of U-Pb isotope data from zircons. A color version of this figure is available online.

nation (e.g., grains 12 , and 13 , fig. $6 b$ ). This age cluster is identical to the $2527 \pm 8 \mathrm{Ma}$ ages obtained from igneous domains in zircons from the tonalite xenolith ZEN-1C and is therefore interpreted to be dating the igneous crystallization of the tonalite. The metamorphic components define a ${ }^{207} \mathrm{~Pb} /{ }^{206} \mathrm{~Pb}$ age cluster at $2447 \pm 12 \mathrm{Ma}$, similar to the $2487 \pm 13 \mathrm{Ma}$ ages obtained from metamorphic zircon in the tonalite ZEN-1C. In CL images, these domains display patchy zoning, have weak CL, and show embayed and irregular resorbed margins (fig. 6b, grains 1, 4, and 13).

Tonalite gneiss (ZEN-2C). Zircon grains in the sample are euhedral and have internal structures typical of igneous zircon. These include oscillatory grow th zonation as well as sector zoning (grains 3, 6, $9,20$, and 21 , fig. $7 b)$. U-Pb spot $(n=19)$ ages from 12 representative grains define a discordia with upper and lower intercept ages of $2533 \pm 9$ and $102 \pm$ $25 \mathrm{Ma}(\mathrm{MSWD}=0.56)$, respectively (fig. 7). The young lower discordia intercept indicates recent alteration of the zircons, a feature similar to zircons from the tonalite ZEN-1C and ZEN-2A. The ${ }^{207} \mathrm{~Pb} /$ ${ }^{206} \mathrm{~Pb}$ ages define a prominent age peak at $2529 \pm$ $9 \mathrm{Ma}$, analytically indistinguishable from the dis- cordia upper intercept age. As with the tonalite (ZEN-1C) and tonalite gneiss (ZEN-2A), the $2529 \pm$ $9 \mathrm{Ma}$ age is interpreted to date the emplacement of the magmatic protolith of the gneiss. A minor age peak at $2456 \pm 21 \mathrm{Ma}$ is similar to the late Neoarchean to early Paleoproterozoic ages from metamorphic zircon in tonalite ZEN-1C and ZEN-2A and is attributed to a metamorphic overprint on the rocks.

Tonalite (ZEN-7A). Most zircon grains show evidence of extensive fluid/melt-induced alteration and plot along a discordia with a young lower intercept age, suggesting recent $\mathrm{Pb}$ loss. The ${ }^{207} \mathrm{~Pb} /$ ${ }^{206} \mathrm{~Pb}$ ages from both concordant and discordant data points define major age peaks at $2445 \pm 9,2380 \pm$ 10 , and $2313 \pm 15 \mathrm{Ma}$. All the three populations are from altered domains that are pitted and characterized by extensive microporosity in the form of irregular patches or fractures (e.g., BSE images of grains 31, 29, 32, 23, and 35, fig. 8b). The altered regions are bright in BSE images (fig. 8b, grains 31 , 19). In some of the grains, core regions are more strongly affected by the alteration, which proceeds inward along irregular fractures (e.g., grains 31, 35, and 19 , fig. $8 b$ ). Such cores are usually U rich, have 


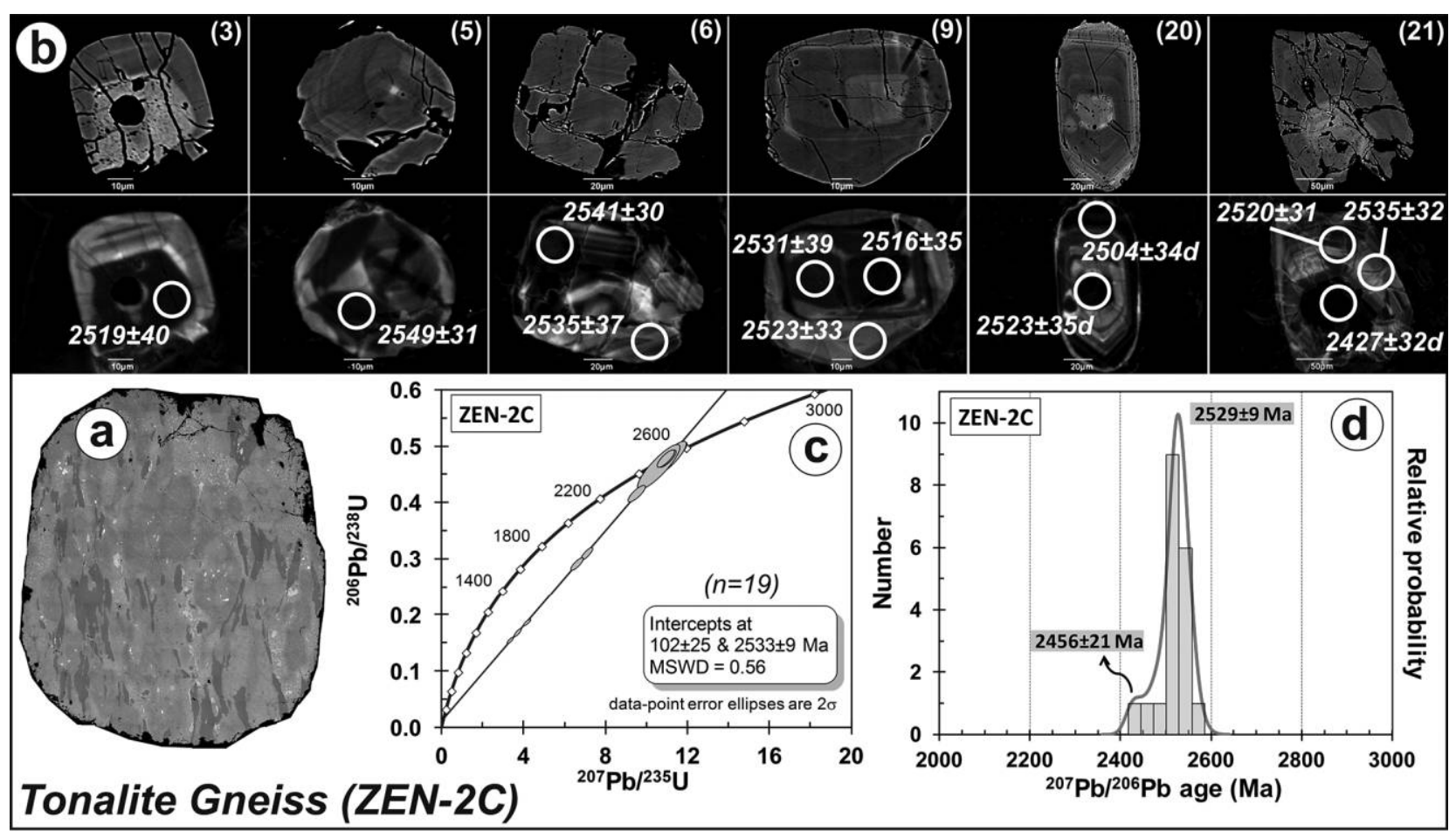

Figure 7. Collage of BSE images showing the overall texture of the tonalite xenolith ZEN-2C $(a)$, BSE and CL images of zircons from the sample with the spot ages marked ( $d$ indicates discordant analysis; $b$ ), concordia $(c)$, and ${ }^{207} \mathrm{~Pb} /{ }^{206} \mathrm{~Pb}$ age relative probability density plots $(d)$, respectively, of U-Pb isotope data from zircons. A color version of this figure is available online.

weak CL response, and are possibly metamict. In other grains, the pitted zones define a narrow rim around cores that display patchy CL and BSE zoning (e.g., grains 23 and 29, fig. 8b). The internal structures of the zircon clearly indicate that the three Paleoproterozoic populations $(2445 \pm 9,2380 \pm 10$, and $2313 \pm 15 \mathrm{Ma}$ ) date metamorphic overprints on the rocks. One zircon grain furnished an older age of $2529 \pm 39 \mathrm{Ma}$ from a domain having a weak CL growth zoning. In consanguinity with the other tonalite xenoliths, the $2529 \pm 39 \mathrm{Ma}$ age dates crystallization of the tonalite. It appears that the metamorphic overprints have almost completely reequilibrated the igneous zircons, accounting for their scarcity.

In summary, the $\mathrm{U}-\mathrm{Pb}$ isotopic compositions of zircons from the four tonalite/tonalite gneiss xenoliths indicate recent to subrecent $\mathrm{Pb}$ loss associated with the emplacement of the Deccan Traps. Igneous components with variably preserved oscillatory growth and sector zoning in all four samples yield a tightly clustered age of $2527 \pm 6 \mathrm{Ma}$ (weighted mean, $2 \sigma_{\text {internal }}$ ), which is interpreted as dating late Neoarchean tonalitic magmatism in the basement of the Deccan Trap lavas. Zircon domains that furnish statistically significant age clusters at $2456 \pm 6$ and $2379 \pm 9 \mathrm{Ma}$ (weighted mean, $2 \sigma_{\text {internal }}$ ) are interpreted to date metamorphic overprints on the rocks.

\section{Discussion and Conclusion}

$\mathrm{Pb}$ Loss in Zircon during Xenolith Entrainment. Zircons in the all the xenolith samples show $\mathrm{Pb}$ loss trends, with the discordia lower intercepts scattering between 102 and $56 \mathrm{Ma}$. The large spread in the lower intercept ages is due to fanning of the discordant analyses from multiple points on the concordia-which date magmatic and metamorphic events - toward the lower intercept. These ages thus might not have any real geological meaning. However, the lower intercepts indicate that the discordance is associated with the disturbance of the $\mathrm{U}-\mathrm{Pb}$ isotope system in the zircons during the entrainment of the xenoliths in the Deccan Trap basalts.

The Deccan basalts had mantle potential temperature of $\sim 1400^{\circ} \mathrm{C}$ (Sen 1995, Sen 2001; White and McKenzie 1995) and eruption temperature of $1125^{\circ}-1200^{\circ} \mathrm{C}$ (Melluso et al. 1995). Although the 


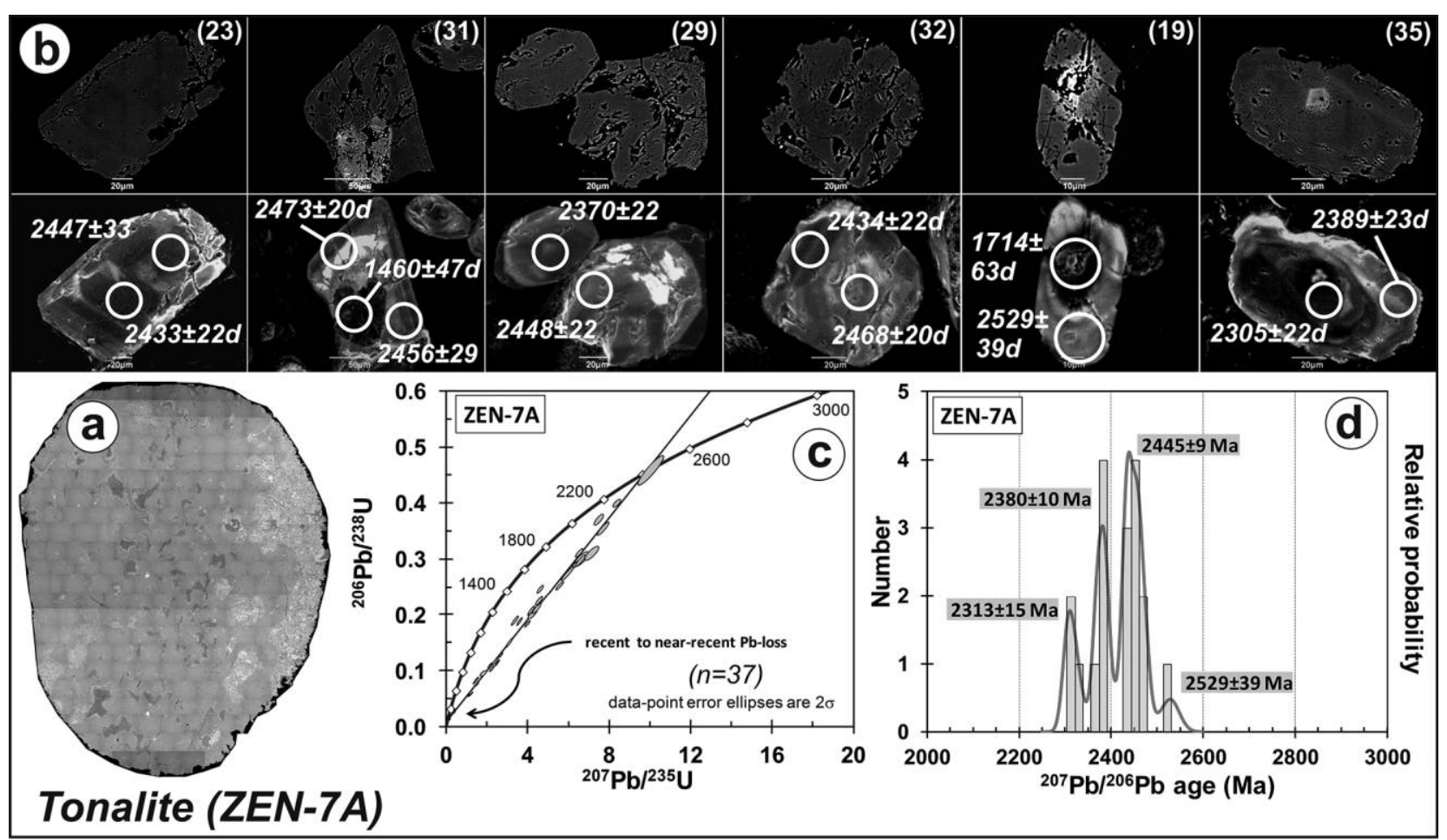

Figure 8. Collage of BSE images showing the overall texture of the tonalite xenolith ZEN-7A $(a)$, BSE and CL images of zircons from the sample with the spot ages marked ( $d$ indicates discordant analysis; $b$ ), concordia $(c)$, and ${ }^{207} \mathrm{~Pb} /{ }^{206} \mathrm{~Pb}$ age relative probability density plots $(d)$, respectively, of U-Pb isotope data from zircons. A color version of this figure is available online.

general consensus is that the bulk of the eruption took place at 65-66 Ma, existing age data show that magmatism continued long after $61 \mathrm{Ma}$ (Lightfoot et al. 1987; Sheth et al. 2001) to ca. $72 \mathrm{Ma}$ (Mahoney et al. 2002). Thus, the entrained xenoliths may have experienced high-temperature conditions for a long period of time. On the basis of numerical modeling, Bea and Montero (2013) have shown that zircon grains shielded and surviving within xenoliths in mafic magmas at temperatures $>1000^{\circ} \mathrm{C}$ can experience high temperatures and develop large disturbances in their $\mathrm{U}-\mathrm{Pb}$ isotopic systematics as a result of enhanced $\mathrm{Pb}$ diffusion in a relatively short time, if they are at least partially metamict before entrainment; only zircons with low U concentrations would remain undisturbed by such a thermal overprint (Kooijman et al. 2011). The Pb loss trends exhibited by zircons from the tonalite xenoliths in this study can be explained by a similar process involving high-temperature diffusive $\mathrm{Pb}$ loss during the entrainment of the xenoliths in the Deccan basalt magmas. The $\mathrm{Pb}$ loss may have been accentuated as a result of the zircons being hosted in feldspars, which have high $\mathrm{Pb}$ partitioning and diffusivity (Cherniak 2010; Bea and Montero 2013).
The Northern Extent of the West Dharwar Craton. The Late Neoarchean $(2.6-2.4 \mathrm{Ga})$ period in the WDC is marked by a major phase of granitoid magmatism and accompanying deformation-metamorphism. Dhoundial et al. (1987) obtained Neoarchean $\mathrm{Rb}$-Sr whole-rock ages from several syn- to post-tectonic granitic plutons in the Goa region (e.g., Chandranath granodiorite/granite: $2650 \pm 100 \mathrm{Ma}$; Dudhsagar granite: $2565 \pm 95 \mathrm{Ma}$; Canacona granite porphyry: $2395 \pm 390 \mathrm{Ma}$ ). More recently, Ishwar Kumar et al. (2013) have reported U-Pb SHRIMP ages of $\sim 2.57 \mathrm{Ga}$ for quartzo-feldspathic gneisses from the Dharwar block. Similar ages $(2.6-2.5 \mathrm{Ga}$, CHIME-monazite) were obtained by Rekha et al. (2013) for the Quepem granitoid in the Goa schist belt. Other parts of the craton also show evidence for extensive Neoarchean felsic magmatism. Acid volcanic rocks of the Chitradurga Group (Dharwar Supergroup/ give a ${ }^{207} \mathrm{~Pb} /{ }^{204} \mathrm{~Pb}-{ }^{206} \mathrm{~Pb} /{ }^{204} \mathrm{~Pb}$ whole-rock isochron age of $2565 \pm 28 \mathrm{Ma}$ (Taylor et al. 1984) and an Rb-Sr isochron age of $2520 \pm 62 \mathrm{Ma}$ (Bhaskar Rao et al. 1992). The Chitradurga granite pluton has a ${ }^{207} \mathrm{~Pb} / 204 \mathrm{~Pb}-{ }^{206} \mathrm{~Pb} /{ }^{204} \mathrm{~Pb}$ whole-rock isochron age of $2605 \pm 18 \mathrm{Ma}$ (Taylor et al. 1984) and a U-Pb zircon age of $2614 \pm 10 \mathrm{Ma}$ (Jayananda et al. 2006). 
Felsic volcanism and granitic intrusion in the Gadag greenstone belt has been dated at $2588 \pm 10$ and $2570 \pm 10 \mathrm{Ma}$, respectively (U-Pb zircon; Sarma et al. 2011). The N-S-trending expansive Closepet batholith, which roughly marks the boundary between the western and eastern parts of the Dharwar craton, was also emplaced in the Neoarchean (ca. $2.52 \mathrm{Ga}$; e.g., Friend and Nutman 1991). The largescale magmatic activity in the craton is broadly synchronous with deformation metamorphism related to the closure of the Goa basin at ca. 2.57 Ga (CHIME monazite; Rekha et al. 2013) and the amalgamation of the Western and Eastern Dharwar Cratons at ca. 2.50 Ga (Friend and Nutman 1991; Chadwick et al. 2000; Moyen et al. 2003; Peucat et al. 2007; Chardon and Jayananda 2008).

The 2.53-Ga tonalitic basement xenoliths within the Deccan Trap dykes at Talvade are thus clearly a part of the expansive Neoarchean granitoid suite of the WDC. That the basement beneath the Deccan Traps has a WDC affinity is also supported by the 2.46-Ga ages obtained from metamorphic domains in zircon from the Talvade and Kihim beach tonalite xenoliths. Similar ages, inferred to be dating late Neoarchean to early Paleoproterozoic metamorphism, have been reported from metacarbonates at Sandur $\left(\sim 2.48 \mathrm{Ga},{ }^{207} \mathrm{~Pb} /{ }^{204} \mathrm{~Pb}-{ }^{206} \mathrm{~Pb} /{ }^{204} \mathrm{~Pb}\right.$ whole-rock isochron; Russell et al. 1996), dolomitediopside-forsterite marble in the Sargur schist belt (2.48-2.46 Ga, TIMS zircon; Sarangi et al. 2007), and phyllites, schists, and polymict conglomerates from the Goa schist belt (CHIME monazite, 2.44-2.46 Ga; Rekha et al. 2013). The significance of the $2370 \pm$ $22 \mathrm{Ma}$ age from a patchy zircon core in xenolith sample ZEN-7A is not clear. It is tentatively correlated with thermal metamorphism associated with the emplacement of the oldest set of mafic dyke swarm within the Dharwar craton at ca. $2.37 \mathrm{Ga}$ (French et al. 2010).

The results of our study clearly establish the following: (1) the basement of the Deccan Trap lavas comprises tonalitic granitoids that were emplaced at $\sim 2.53 \mathrm{Ga}$ and metamorphosed/deformed at $\sim 2.46$ and $2.37 \mathrm{Ga}$; (2) the tonalitic basement below the Deccan Traps is a part of the expansive Neoarchean granitoid suite of the WDC; (3) the geological evolution of the basement rocks below the Deccan Traps is similar to that of the other parts of the WDC; and (4) the WDC forms the basement to the Deccan Traps lavas, and the cratonic nucleus extends northward up to at least Talvade in the central Deccan and Kihim beach in the western Deccan Traps.

On the basis of CHIME monazite ages, Rekha and Bhattacharya (2014) inferred that the Pernem-
Phonda tectonic zone/South Maharashtra Shear Zone represents a crustal domain formed by longlived Proterozoic tectonism $(\sim 2.4-1.7 \mathrm{Ga})$. The authors documented a northward younging of metamorphic episodes across the zone and suggested that the Pernem-Phonda crustal domain was a terrane boundary that limited the northern extent of the WDC. This is not supported by the new zircon age data from the basement xenoliths, which instead show that the WDC extends northward beyond the Pernem-Phonda corridor, thereby necessitating a reevaluation of the status of the Pernem-Phonda tectonic zone/South Maharashtra Shear Zone.

Paleoproterozoic to Mesoproterozoic ages similar to those for the Pernem-Phonda corridor (e.g., Rekha and Bhattacharya 2014) have also been reported by Ishwar Kumar et al. (2013) from the Kumta suture and the neighboring Karwar and Dharwar blocks. These authors obtained CHIME ages of $\sim 1.70$ Ga from zircon rims in quartz-phengite-schist from the Kumta suture and K-Ar biotite ages of 1.55$1.64 \mathrm{Ga}$ from the Bondla ultramafic-gabbro complex. They also reported Paleoproterozoic K-Ar biotite ages of $\sim 1.73$ and $1.75-1.80$ Ga from quartzofeldspathic gneisses in the Dharwar block and tonalite-trondhjemite-granodiorites of the Karwar block, respectively. Ishwar Kumar et al. (2013) have interpreted the Paleoproterozoic ages to be dating uplift of the Karwar and Dharwar blocks before their suturing. Thus, the Pernem-Phonda tectonic zone/South Maharashtra Shear Zone could be either (1) intracontinental shear zone within the Dharwar block or (2) suture between the Karwar block and the Dharwar block and therefore equivalent to the Kumta suture.

Correlation with Madagascar. Though the status of the Betsimisaraka suture and its continuation into India as the Kumta suture is still debated, paleogeographic reconstructions juxtaposing Madagascar against India until their late Cretaceous separation is supported by geochronological (e.g., Tucker et al. 1999a, 2011a, 2011b, 2014; Collins and Windley 2002; Collins et al. 2003; Cox et al. 2004; Collins and Pisarevsky 2005; Collins 2006; Schofield et al. 2010; Ishwar Kumar et al. 2013; Rekha et al. 2013, 2014; Rekha and Bhattacharya 2014; Zhou et al. 2015) and geophysical (Chand and Subrahmanyam 2003; Ratheesh Kumar et al. 2014) studies. In a recent study, Ratheesh Kumar et al. (2014) identified zones of conjugate rift-related lithospheric thinning/deformation along the western continental margin of India and the eastern continental margin of Madagascar on the basis of effective elastic thickness of the lithosphere. These zones were inferred to represent the paleo-rift in- 
ception points. There is also a close-fit correlation of Moho geometry and bathymetry of the shelf margins for the two continents.

The existence of 2.53-Ga WDC granitoids below the Deccan Traps further adds to the growing body of evidence supporting the existence of a Neoarchean GDC comprising the WDC of India and the AntongilMasora Block of Madagascar. These WDC granitoids can be correlated with the expansive Neoarchean felsic intrusives (2.57-2.49 Ga; Tucker et al. 1999b, 2014; Paquette et al. 2003; Schofield et al. 2010) of the Masaola suite in the Antongil Block of Madagascar. Contrary to observations by Rekha et al. (2013) that late Archean intrusive rocks are spatially restricted along the Konkan coast, this study provides evidence for the existence of an expansive suite of granitoid rocks in the northern part of the WDC similar to those in the Antongil Block. The lack of Neoarchean rocks along the Konkan coast is therefore apparent only because the Neoarchean basement lies covered by the Deccan Trap volcanic rocks.

\section{A C K N OWLEDGMENTS}

We thank an anonymous reviewer and the editor whose constructive comments helped to improve the article. This project was supported by grants to D. Upadhyay (Indian Institute of Technology Kharagpur Institute Scheme for Innovative Research and Development research grant) and to K. Mezger (Deutsche Forschungsgemeinschaft, Leibniz Award, ME 1717/18-1).

\section{REFERENCES CITED}

Agrawal, P. K.; Pandey, O. P.; and Negi, J. G. 1992. Madagascar: a continental fragment of paleo-super Dharwar craton of India. Geology 20:543-546.

Balasubramanian, M. N., and Sarkar, A. 1978. K-Ar ages of a suite of Lower Paleozoic post-tectonic granites, southern India. In Zartman, R. E., ed. 4th International Conference on Geochronology, Cosmochronology, Isotope Geology in USA. Geol. Surv. Open File Reps. 78-101, p. 19-20.

Bea, F., and Montero, P. 2013. Diffusion-induced disturbances of the $\mathrm{U}-\mathrm{Pb}$ isotope system in pre-magmatic zircon and their influence on SIMS dating: a numerical study. Chem. Geol. 349/350:1-17.

Beane, J. E.; Turner, C. A.; Hooper, P. R.; Subbarao, K. V.; and Walsh, J. N. 1986. Stratigraphy, composition and form of the Deccan Basalts, Western Ghats, India. Bull. Volcanol. 48:61-83.

Beckinsale, R. D.; Drury, S. A.; and Holt, R. W. 1980. 3360 Myr old gneisses from the south Indian craton. Nature 283:469-470.

Bhaskar Rao, Y. J.; Sivaraman, T. V.; Pantulu, G. V. C.; Gopalan, K.; and Naqvi, S. M. 1992. Rb-Sr ages of late Archaean metavolcanics and granites, Dharwar craton, south India, and evidence for early Proterozoic thermotectonic events. Precambrian Res. 59:145170 .

Blasband, B.; White, S. H.; Brooijmans, P.; Visser, W.; and De Boorder, H. 2000. Late Proterozoic extensional collapse in the Arabian-Nubian Shield. J. Geol. Soc. Lond. 157:615-628.

Bouhallier, H.; Chardon, D.; and Choukroune, P. 1995. Strain patterns in Archean dome-and-basin structures: the Dharwar craton (Karnataka, south India). Earth Planet. Sci. Lett. 135:57-75.

Bouhallier, H.; Choukroune, P.; and Ballèvre, M. 1993. Diapirism, bulk homogenous shortening and transcurrent shearing in the Archean Dharwar craton: the Holenarsipur area. Precambrian Res. 63:43-58.
Chadwick, B.; Vasudev, V. N.; and Hedge, G. V. 2000. The Dharwar craton, southern India, interpreted as the result of Late Archean oblique convergence. Precambrian Res. 99:91-101.

Chand, S., and Subrahmanyam, C. 2003. Rifting between India and Madagascar mechanism and isostasy. Earth Planet. Sci. Lett. 210:317-332.

Chardon, D., and Jayananda, M. 2008. Three-dimensional field perspective on deformation, flow, and growth of the lower continental crust (Dharwar craton, India). Tectonics 27:TC1014.

Cherniak, D. J. 2010. Cation diffusion in feldspars. Rev. Mineral. Geochem. 72:691-734.

Collins, A. S. 2006. Madagascar and the amalgamation of Central Gondwana. Gondwana Res. 9:3-16.

Collins, A. S.; Fitzsimons, I.; Kinny, P. D.; Brewer, T. S.; Windley, B. F.; Kröner, A.; and Razakamanana, T. 2001. The Archaean rocks of Central Madagascar: their place in Gondwana. In Cassidy, K. F.; Dunphy, J. M.; and Van Kranendonk, M. J., eds. 4th International Archaean Symposium Extended Abstracts. Australia, AGSO-Geoscience, p. 294-296.

Collins, A. S.; Kröner, A.; Fitzsimons, I. C. W.; and Razakamanana, T. 2003. Detrital footprint of the Mozambique Ocean: U/Pb SHRIMP and $\mathrm{Pb}$ evaporation zircon geochronology of metasedimentary gneisses in eastern Madagascar. Tectonophysics 375:77-99.

Collins, A. S., and Pisarevsky, S. A. 2005. Amalgamating eastern Gondwana: the evolution of the Circum-Indian Orogens. Earth Sci. Rev. 71:229-270.

Collins, A. S.; Razakamanana, $\mathrm{T}_{\text {; }}$ and Windley, B. F. 2000. Neoproterozoic extensional detachment in central Madagascar: implications for the collapse of the East African Orogen. Geol. Mag. 137:39-51.

Collins, A. S., and Windley, B. F. 2002. The tectonic evolution of central and northern Madagascar and its place in the final assembly of Gondwana. J. Geol. 110: $325-340$ 
Cox, R.; Armstrong, R. A.; and Ashwal, L. D. 1998. Sedimentology, geochronology and provenance of the Proterozoic Itremo Group, central Madagascar, and implications for pre-Gondwana palaeogeography. J. Geol. Soc. Lond. 155:1009-1024.

Cox, R.; Coleman, D. S.; Chokel, C. B.; De Oreo, S. B.; Wooden, J. L.; Collins, A. S.; De Waele, B.; and Kröner, A. 2004. Proterozoic tectonostratigraphy and paleogeography of central Madagascar derived from detrital zircon U-Pb age populations. J. Geol. 112:379-400.

Dessai, A. G., and Viegas, A. A. A. A. 1995. Multigeneration mafic dyke swarm related to Deccan magmatism, south of Bombay: implications on the evolution of the western Indian continental margin. In Devaraju, T. C., ed. Dyke swarms of peninsular India. Geol. Soc. India Mem. 33:435-451.

De Waele, B.; Thomas, R. J.; Macey, P. H.; Horstwood, M. S. A.; Tucker, R. D.; Pitfield, D. P. E. J.; Schofield, I.; et al. 2011. Provenance and tectonic significance of the Palaeoproterozoic metasedimentary successions of central and northern Madagascar. Precambrian Res. 189:18-42.

De Wit, M. J. 2003. Madagascar: heads it's a continent, tails it's an island. Annu. Rev. Earth Planet. Sci. 31: 213-248.

Dhoundial, D. P.; Sarkar, D. K.; Trivedi, J. R.; Gopalan, K.; and Potts, P. J. 1987. Geochronology and geochemistry of Precambrian granitic rocks of Goa, southwest India. Precambrian Res. 36:287-302.

Fitzsimons, I. C. W., and Hulscher, B. 2005. Out of Africa: detrital zircon provenance of central Madagascar and Neoproterozoic terrane transfer across the Mozambique Ocean. Terra Nova 17:224-235.

French, J. E., and Heaman, L. M. 2010. Precise U-Pb dating of Paleoproterozoic mafic dyke swarms of the Dharwar craton, India: implications for the existence of the Neoarchean supercraton Sclavia. Precambrian Res. 183:416-441.

Friend, C. R. L., and Nutman, A. P. 1991. Shrimp U-Pb geochronology of the Closepet granite and peninsular gneiss, Karnataka, South-India. J. Geol. Soc. India 38: 357-368.

Goncalves, P.; Nicollet, C.; and Lardeaux, J.-M. 2000. In situ electron microprobe monazite dating of the complex retrograde evolution of UHT granulites from Andriamena (Madagascar): apparent petrographical path vs. P-T-t path. Geol. Soc. Am. Abstr. Program 32: A174-A175.

Gupta, J. N.; Pandey, B. K.; Prasad, R. N.; Yadav, G. S.; Ramesh Kumar, K.; and Rao, S. S. 1988. Rb-Sr geochronology of some granitic rocks around Arbail and age of uraniferous arenite and quartz-pebble-conglomerates of Western Karnataka. Mem. Geol. Soc. India 9:101-108.

Ishwar-Kumar, C.; Windley, B. F.; Horie, K.; Kato, T.; Hokada, T.; Itaya, T.; Yagi, K.; Gouzu, C.; and Sajeev, K. 2013. A Rodinian suture in western India: new insights on India-Madagascar correlations. Precambrian Res. 236:227-251.
Jackson, S. E.; Pearson, N. J.; Griffin, W. L.; and Belousova, E. A. 2004. The application of laser ablationinductively coupled plasma-mass spectrometry to insitu U-Pb zircon geochronology. Chem. Geol. 211:47-69.

Janardhan, A. S.; Ramachandra, H. M.; and Ravindra Kumar, G. R. 1979. Structural history of Sargur supracrustals and associated gneisses south-west of Mysore, Karnataka. J. Geol. Soc. India 20:61-72.

Jayananda, M.; Chardon, D.; Peucat, J.-J.; and Capdevila, R. 2006. 2.61 Ga potassic granites and crustal reworking in the Western Dharwar Craton, southern India: tectonic, geochronologic and geochemical constraints. Precambrian Res. 150:1-26.

Jayananda, M.; Martin, H.; Peucat, J.-J.; and Mahabaleshwar, B. 1995. Late Archaean crust-mantle interactions: geochemistry of LREE-enriched mantle derived magmas: example of the Closepet batholith, south India. Contrib. Mineral. Petrol. 119:314-329.

Jayananda, M.; Moyen, J.-F.; Martin, H.; Peucat, J.-J.; Auvray, B.; and Mahabaleswar, B. 2000. Late Archaean (2550-2520 Ma) juvenile magmatism in the Eastern Dharwar craton, southern India: constraints from geochronology, Nd-Sr isotopes and whole rock geochemistry. Precambrian Res. 99:225-254.

Katz, M. B., and Premoli, C. 1979. India and Madagascar in Gondwanaland based on matching Precambrian lineaments. Nature 279:312-315.

Kooijman, E.; Berndt, J.; and Mezger, K. 2012. U-Pb dating of zircon by laser ablation ICP-MS: recent improvements and new insights. Eur. J. Mineral. 24:5-21.

Kooijman, E.; Upadhyay, D.; Mezger, K.; Raith, M. M.; Berndt, J.; and Srikantappa, C. 2011. Response of the $\mathrm{U}-\mathrm{Pb}$ chronometer and trace elements in zircon to ultrahigh-temperature metamorphism: the Kadavur anorthosite complex, southern India. Chem. Geol. 290: 177-188.

Kröner, A.; Hegner, E; Collins, A. S.; Windley, B. F.; Brewer, T. S.; Razakamanana, T.; and Pidgeon, R. T. 2000. Age and magmatic history of the Antanarivo Block, central Madagascar, as derived from zircon geochronology and $\mathrm{Nd}$ isotopic systematics. Am. J. Sci. 300:251-288.

Lightfoot, P. C.; Hawkesworth, C. J.; and Sethna, S. F. 1987. Petrogenesis of rhyolites and trachytes from the Deccan Trap: Sr, Nd and Pb isotope and trace element evidence. Contrib. Mineral. Petrol. 95:44-54.

Ludwig, K. R. 2003. User's manual for Isoplot 3.00: a geochronological toolkit for Microsoft Excel. Berkeley Geochronology Center Spec. Publ. 4.

Mahoney, J. J.; Duncan, R. A.; Khan, W.; Gnos, E.; and McCormick, G. R. 2002. Cretaceous volcanic rocks of the South Tethyan suture zone, Pakistan: implications for the Réunion hotspot and Deccan Traps. Earth. Planet. Sci. Lett. 203:295-310.

McWilliams, M. O. 1981. Paleomagnetism and Precambrian tectonic evolution of Gondwana. In Kröner, A., ed. Precambrian plate tectonics. Amsterdam, Elsevier, p. 649-687. 
Meen, J. K.; Rogers, J. J. W.; and Fullagar, P. D. 1992. Lead isotopic compositions of the Western Dharwar Craton, southern India: evidence for distinct Middle Archean terranes in a Late Archean craton. Geochim. Cosmochim. Acta 56:2455-2470.

Meert, J. G. 2003. A synopsis of events related to the assembly of eastern Gondwana. Tectonophysics 362:140.

Meert, J. G.; Van der Voo, R.; and Ayub, S. 1995. Paleomagnetic investigation of the Late Proterozoic Gagwe lavas and Mbozi complex, Tanzania and the assembly of Gondwana. Precambrian Res. 69:113-131.

Melluso, L.; Beccaluva, L.; Brotzu, P.; Gregnanin, A.; Gupta, A. K.; Morbidelli, L.; and Traversa, G. 1995. Constraints on the mantle sources of the Deccan Traps from the petrology and geochemistry of the basalts of Gujarat State (Western India). J. Petrol. 36: 1393-1432.

Moyen, J. F.; Martin, H.; Jayananda, M.; and Auvray, B., 2003. Late Archean granites: a typology based on the Dharwar Craton (India). Precambrian Res. 127:103123.

Naqvi, S. M., and Rogers, J. J. W. 1987. Precambrian geology of India. Oxford, Oxford University Press, $223 \mathrm{p}$.

Nutman, A. P.; Chadwick, B.; Ramakrishnan, M.; and Viswanatha, M. N. 1992. SHRIMP U-Pb ages of detrital zircon in Sargur supracrustal rocks in western Karnataka, southern India. J. Geol. Soc. India 39:367374.

O'Neill, C.; Müller, D.; and Steinberger, B. 2003. Geodynamic implications of moving Indian Ocean hotspots. Earth Planet. Sci. Lett. 205:151-168.

Pandey, K. 2002. Age and duration of the Deccan Traps, India: a review of radiometric and paleomagnetic constraints. Proc. Indian Acad. Sci (Earth Planet. Sci.) 111: 115-123.

Paquette, J. L.; Moine, B.; and Rakotondrazafy, M. A. F. 2003. ID-TIMS using the stepwise dissolution technique versus ion microprobe $\mathrm{U}-\mathrm{Pb}$ dating of metamict Archean zircons from NE Madagascar. Precambrian Res. 121:73-84.

Peucat, J. J.; Bouhallier, H.; Fanning, C. M.; and Jayananda, M. 1995. Age of the Holenarsipur Greenstone Belt: relationships with the surrounding gneisses (Karnataka, South India). J. Geol. 103:701-710.

Peucat, J. J.; Mahabaleswar, B.; and Jayananda, M. 2007. Age of younger tonalitic magmatism and granulitic metamorphism in the South Indian transition zone (Krishnagiri area): comparison with older Peninsular gneisses from the Gorur-Hassan area. J. Metamorph. Geol. 11:879-888.

Peucat, J.-J.; Mahabaleswar, M.; and Jayananda, M. 1993. Age of younger tonalitic magmatism and granulite metamorphism in the amphibolite-granulite transition zone of southern India (Krishnagiri area): comparison with older Peninsular gneisses of Gorur-Hassan area. J. Metamorph. Geol. 11:879-888.
Ramakrishnan, M., and Vaidyanadhan, R. 2008. Geology of India. Bangalore, Publ. Geol. Soc. India, 556 p.

Ratheesh-Kumar, R. T.; Ishwar-Kumar, C.; Windley, B. F.; Razakamanana, T.; Nair, R. R.; and Sajeev, K. 2014. India-Madagascar paleo-fit based on flexural isostasy of their rifted margins. Gondwana Res., doi:10.1016 /j.gr.2014.06.008.

Ray, R.; Sheth, H. C.; and Mallik, J. 2007. Structure and emplacement of the Nandurbar-Dhule mafic dyke swarm, Deccan Traps, and the tectonomagmatic evolution of flood basalts. Bull. Volcanol. 69:537-551.

Ray, R.; Shukla, A. D.; Sheth, H. C.; Ray, J. S.; Duraiswami, R. A.; Vanderkluysen, L.; Rautela, C. S.; and Mallik, J. 2008. Highly heterogeneous Precambrian basement under the central Deccan Traps, India: direct evidence from xenoliths in dykes. Gondwana Res. 13:375-385.

Rekha, S., and Bhattacharya, A. 2014. Paleoproterozoic/ Mesoproterozoic tectonism in the northern fringe of the Western Dharwar Craton (India): its relevance to Gondwanaland and Columbia supercontinent reconstructions. Tectonics 33:552-580.

Rekha, S.; Bhattacharya, A.; and Chatterjee, N. 2014. Tectonic restoration of the Precambrian crystalline rocks along the west coast of India: correlation with eastern Madagascar in East Gondwana. Precambrian Res. 252:191-208.

Rekha, S.; Viswanath, T. A.; Bhattacharya, A.; and Prabhakar, N. 2013. Meso/Neoarchean crustal domains along the north Konkan coast, western India: the Western Dharwar Craton and the Antongil-Masora Block (NE Madagascar) connection. Precambrian Res. 233:316-336.

Russell, J.; Chadwick, B.; Krishna Rao, B.; and Vasudev, V. N. 1996. Whole-rock $\mathrm{Pb} / \mathrm{Pb}$ isotopic ages of Late Archean limestones, Karnataka, India. Precambrian Res. 78:261-272.

Sambridge, M. S., and Compston, W. 1994. Mixture modelling of multicomponent data sets with application to ion-probe zircon ages. Earth Planet. Sci. Lett. 128:373390.

Sant, D. A., and Karanth, R. V. 1990. Emplacement of dyke swarms in the Lower Narmada valley, western India. In Parker, A. J.; Rickwood, P. C.; and Tucker, D. H., eds. Mafic dykes and emplacement mechanisms. Rotterdam, Balkema, p. 383-389.

Sarangi, S.; Gopalan, K.; and Srinivasan, R. 2007. Small scale sampling for $\mathrm{Pb}-\mathrm{Pb}$ dating of marbles: example from the Sargur supracrustal rocks, Dharwar Craton, South India. Precambrian Res. 152:83-91.

Sarma, D. S.; Fletcher, I. R.; Rasmussen, B.; McNaughton, N. J.; Ram Mohan, M.; and Groves, D. I. 2011. Archean gold mineralization synchronous with late cratonization of the Western Dharwar Craton India: $2.52 \mathrm{Ga}$ $\mathrm{U}-\mathrm{Pb}$ ages of hydrothermal monazite and xenotime in gold deposits. Mineral. Deposita 46:273-288.

Schofield, D. I.; Thomas, R. J.; Goodenough, K. M.; De Waele, B.; Pitfield, P. E. J.; Key, R. M.; Bauer, W.; et al. 
2010. Geological evolution of the Antongil Craton, NE Madagascar. Precambrian Res. 182:187-203.

Sen, G. 1995. A simple petrologic model for the generation of Deccan Trap magmas. Int. Geol. Rev. 37:825-850.

. 2001. Generation of Deccan trap basalt. Proc. Natl. Acad. Sci. India 110:409-431.

Sheth, H. C.; Pande, K.; and Bhutani, R. 2001. ${ }^{40} \mathrm{Ar}-{ }^{39} \mathrm{Ar}$ ages of Bombay trachytes: evidence for a Paleocene phase of Deccan volcanism. Geophys. Res. Lett. 28: 3513-3516.

Sommer, H.; Kröner, A.; Hauzenberger, C.; Muhongo, S.; and Wingate, M. T. D. 2003. Metamorphic petrology and zircon geochronology of high-grade rocks from the central Mozambique Belt of Tanzania: crustal recycling of Archean and Palaeo-proterozoic material during the Pan-African orogeny. J. Metamorph. Geol. 21: 915-934.

Stern, R. J. 1994. Arc assembly and continental collision in the Neoproterozoic East Africa Orogen: implications for the consolidation of Gondwanaland. Annu. Rev. Earth Planet. Sci. 22:319-351.

Story, M.; Mahoney, J. J.; Saunders, A. D.; Duncan, R. A.; Kelly, S. K.; and Coffin, M. F. 1995. Timing of hot spotrelated volcanism and the break-up of Madagascar and India. Science 267:852-855.

Swami Nath, J., and Ramakrishnan, M. 1981. Early Precambrian supracrustals of Southern Karnataka. Geol. Surv. India Mem. 112:351.

Swami Nath, J.; Ramakrishnan, M.; and Viswanatha, M. N. 1976. Dharwar stratigraphic model and Karnataka craton evolution. Rec. Geol. Surv. India 107:149_ 175.

Taylor, P. N.; Chadwick, B.; Moorbath, S.; Ramakrishnan, M.; and Viswanatha, M. N. 1984. Petrography, chemistry and isotopic ages of Peninsular Gneiss, Dharwar acid volcanic rocks and the Chitradurga granite with special reference to the late Archean evolution of the Karnataka craton. Precambrian Res. 23:349375.

Torsvik, T. H.; Tucker, R. D.; Ashwal, L. D.; Carter, L. M.; Jamtveit, B.; Vidyadharan, K. T.; and Venkataramana, P. 2000. Late Cretaceous India-Madagascar fit and timing of break-up related magmatism. Terra Nova 12: 220-224.

Torsvik, T. H.; Tucker, R. D.; Ashwal, L. D.; Eide, E. A.; Rakotosolofo, N. A.; and de Wit, M. J. 1998. Later Cretaceous magmatism in Madagascar: paleomagnetic evidence for a stationary Marion hotspot. Earth Planet. Sci. Lett. 164:221-232.

Tucker, R. D.; Ashwal, L. D.; Hamilton, M. A.; Torsvik, T. H.; and Carter, L. M. 1999a. Neoproterozoic silicic magmatism of northern Madagascar, Seychelles, and
NW India: clues to Rodinia's assembly and dispersal. Geol. Soc. Am. Abstr. Programs 31:317.

Tucker, R. D.; Ashwal, L. D.; Handke, M. J.; Hamilton, M. A.; Le Grange, M.; and Rambeloson, R. A. $1999 b$. $\mathrm{U}-\mathrm{Pb}$ geochronology and isotope geochemistry of the Archean and Proterozoic rocks of north-central Madagascar. J. Geol. 107:135-153.

Tucker, R. D.; Roig, J. Y.; Delor, C.; Amelin, Y.; Goncalves, P.; Rabarimanana, M. H.; Ralison, A. V.; and Belcher, R. W. 2011a. Neoproterozoic extension in the Greater Dharwar Craton: a re-evaluation of the Betsimisaraka suture in Madagascar. Can. J. Earth Sci. 48:389-417.

Tucker, R. D.; Roig, J. Y.; Macey, P. H.; Delor, C.; Amelin, Y.; Armstrong, R. A.; Rabarimanana, M. H.; and Ralison, A. V. 2011b. A new geological framework for south-central Madagascar, and its relevance to the outof-Africa hypothesis. Precambrian Res. 185:109-130.

Tucker, R. D.; Roig, J. Y.; Moine, B.; Delor, C.; and Peters, S. G. 2014. A geological synthesis of the Precambrian shield in Madagascar. J. Afr. Earth Sci., doi:10.1016 /j.jafrearsci.2014.02.001.

Unrug, R., ed. 1996. Geodynamic map of Gondwana supercontinent assembly, scale 1:10 Million. Orleans, France, Bureau de Recherches Geologiques et Minieres.

Vandamme, D.; Courtillot, V.; Besse, J; and Montigny, R. 1991. Paleomagnetism and age determinations of the Deccan Traps (India): results of a Nagpur-Bombay traverse and review of earlier work. Rev. Geophys. 29: 159-190.

Veevers, J. J. 2004. Gondwanaland from 650-500 Ma assembly through 320 Mamerger in Pangea to $185-100 \mathrm{Ma}$ breakup: supercontinental tectonics viastratigraphy and radiometric dating. Earth-Sci. Rev. 68:1-132.

White, R., and McKenzie, D. 1995. Mantle plumes and flood basalts. J. Geophys. Res. 100:17543-17585.

Wiedenbeck, M.; Allé, P.; Corfu, F.; Griffn, W. L.; Meier, M.; Oberli, F.; Von Quart, A.; Roddick, J. C.; and Spiegel, W. 1995. Three natural zircon standards for U-Th-Pb, Lu-Hf, trace element and REE analyses. Geostandard Newsl. 19:1-23.

Windley, B. F.; Razafiniparany, A.; Razakamanana, T.; and Ackermand, D. 1994. Tectonic framework of the Precambrian of Madagascar and its Gondwana connections: a review and reappraisal. Geol. Rundsch. 83: 642-659.

Zhou, J. L.; Shao, S.; Luo, Z. H.; Shao, J. B.; Wu, D. T.; and Rasoamalala, V. 2015. Geochronology and geochemistry of Cryogenian gabbros from the Ambatondrazaka area, east-central Madagascar: implications for Madagascar-India correlation and Rodinia paleogeography. Precambrian Res. 256:256-270. 